\section{Validation of a Fertilizer Potential Acidity Model to Predict the Effects of Water-soluble Fertilizer on Substrate pH}

\author{
Paul R. Fisher ${ }^{1,4}$ \\ Environmental Horticulture Department, University of Florida, 2549 Fifield \\ Hall, Gainesville, FL 32611-0670
}

William R. Argo ${ }^{2}$

Blackmore Company, Belleville, MI 48111

\author{
John A. Biernbaum ${ }^{3}$ \\ Department of Horticulture, Michigan State University, East Lansing, MI \\ 48824-1325
}

Additional index words. basicity, growing media, impatiens, limestone, nitrogen CCE, peat, petunia, pelargonium, $\mathrm{pH}$ management, soilless media, water-soluble fertilizer

\begin{abstract}
Two experiments were run to validate a "Nitrogen Calcium Carbonate Equivalence (CCE)" model that predicts potential fertilizer basicity or acidity based on nitrogen $(N)$ form and concentration for floriculture crops grown with water-soluble fertilizer in containers with minimal leaching. In one experiment, nine bedding plant species were grown for 28 days in a peat-based substrate using one of three nutrient solutions (FS) composed of three commercially available water-soluble fertilizers that varied in ammonium to nitrate $\left(\mathrm{NH}_{4}{ }^{+}: \mathrm{NO}_{3}{ }^{-}\right)$ratio $(40: 60,25: 75$, or 4:96) mixed with well water with $130 \mathrm{mg} \cdot \mathrm{L}^{-1}$ calcium carbonate $\left(\mathrm{CaCO}_{3}\right)$ alkalinity. Both the ammoniumnitrogen $\left(\mathrm{NH}_{4}-\mathrm{N}\right)$ content of the $\mathrm{FS}$ and plant species affected substrate $\mathrm{pH}$. Predicted acidity or basicity of the FS for Impatiens walleriana Hook.f. (impatiens), Petunia $\times$ hybrida E. Vilm. (petunia), and Pelargonium hortorum L.H. Bailey (pelargonium) from the Nitrogen CCE model was similar to observed $\mathrm{pH}$ change with an adjusted $R^{2}$ of 0.849 . In a second experiment, water alkalinity $\left(0\right.$ or $\left.135.5 \mathrm{mg} \cdot \mathrm{L}^{-1} \mathrm{CaCO}_{3}\right), \mathrm{NH}_{4}^{+}: \mathrm{NO}_{3}{ }^{-}$ratio (75:25 or 3:97), and $N$ concentration $\left(50,100\right.$, or $\left.200 \mathrm{mg} \cdot \mathrm{L}^{-1} \mathrm{~N}\right)$ in the FS were varied with impatiens. As predicted by the $\mathrm{N}$ CCE model, substrate pH decreased as $\mathrm{NH}_{4}^{+}$ concentration increased and alkalinity decreased with an adjusted $R^{2}$ of 0.763 . Results provide confidence in the N CCE model as a tool for fertilizer selection to maintain stable substrate $\mathrm{pH}$ over time. The limited scope of these experiments emphasizes the need for more research on plant species effects on substrate $\mathrm{pH}$ and interactions with other factors such as residual limestone and substrate components to predict $\mathrm{pH}$ dynamics of containerized plants over time.
\end{abstract}

Substrate $\mathrm{pH}$ must be carefully managed to control nutrient availability in container substrates (Peterson, 1981). A number of factors that include substrate components, limestone type and rate, the irrigation water source

Received for publication 19 Feb. 2014. Accepted for publication 15 June 2014.

We acknowledge the Michigan State University AgBioResearch, University of Florida IFAS, sponsors of the Floriculture Research Alliance (floriculturealliance.org), and the Blackmore Company for supporting this research. Plant material was provided by Pinter Brothers Greenhouse, Ypsilanti, MI, and Knox Nursery, Winter Garden, FL.

The use of trade names in this publication does not imply endorsement of the products named or criticism of similar ones not mentioned.

${ }^{1}$ Professor

${ }^{2}$ Technical Manager, Blackmore Co

${ }^{3}$ Professor.

${ }^{4}$ To whom reprint requests should be addressed; e-mail PFisher@ufl.edu.
(IWS), plant species, and water-soluble fertilizer (WSF) interact to affect the nutrient supply in container substrate throughout crop production (Argo and Biernbaum, 1996, 1997). A key grower decision is the selection of the WSF formulation and concentration to maintain a stable substrate $\mathrm{pH}$ over time. This is particularly challenging given the range in iron efficiency of floriculture crop species, which affect both tendencies to either raise or lower $\mathrm{pH}$ and susceptibility to either iron deficiency at high $\mathrm{pH}$ or iron/manganese toxicity at low $\mathrm{pH}$ (Argo and Fisher, 2002).

With agronomic crops, some species reduce susceptibility to high $\mathrm{pH}$-induced iron chlorosis through an ability to lower (acidify) the rhizosphere $\mathrm{pH}$ through root exudation of $\mathrm{H}^{+}$and organic acid (citrate, malate) when grown in calcareous soils ( $\mathrm{pH}$ greater than 7.8). In contrast, species that do not lower the rhizosphere $\mathrm{pH}$ are much more susceptible to lime-induced iron chlorosis (Marschner, 1995). Among cultivars of the same species, there may be considerable differences in the susceptibility of high $\mathrm{pH}$-induced iron chlorosis because of differences in their ability to lower the rhizosphere $\mathrm{pH}$ (Froehlich and Fehr, 1981; Saxena and Sheldrake, 1980).

In floriculture crops, much less is known of species or cultivar effects on substrate $\mathrm{pH}$ and the resulting differences in nutrient uptake. In laboratory experiments on germinating seedlings, Bailey et al. (1996) found that substrate $\mathrm{pH}$ varied from 4.5 with $\mathrm{Lyco}$ persicon esculentum Mill. (tomato) to 7.5 with Zinnia hybrida Roem. \& Usteri (zinnia) under the same conditions. In greenhouse experiments, Argo and Biernbaum (1997) found that the average substrate $\mathrm{pH}$ of 10 potted plant species given the same WSF [20N-4.3P-16.6K Peatlite Special (Scotts, Marysville, $\mathrm{OH}$ )] ranged from 5.1 with Saintpaulia ionantha Wendl. (African violets) to 6.5 with Gerbera jamesonii Bolus ex Hook. (gerbera). In addition, WSF concentration also influenced substrate $\mathrm{pH}$. For example, the substrate $\mathrm{pH}$ of gerbera decreased from 7.1 to 5.8 as the $\mathrm{N}$ concentration of the WSF increased from 50 to $200 \mathrm{mg}$. $\mathrm{L}^{-1}$, whereas the substrate $\mathrm{pH}$ decreased from 5.2 to 4.8 with African violets over the same range of WSF concentrations.

Johnson et al. (2013) showed that the majority of the WSF effect on substrate $\mathrm{pH}$ could be modeled based on the concentration of different $\mathrm{N}$ forms $\left(\mathrm{NH}_{4}{ }^{+}, \mathrm{NO}_{3}{ }^{-}\right.$, or urea) despite a wide range in concentration of other ions. By analyzing the observed $\mathrm{pH}$ change for impatiens, petunia, and pelargonium, with a number of WSF formulations, parameters were developed for each $\mathrm{N}$ form and plant species. Estimated milliequivalents (meq) of acid (negative values) or base (positive values) per mmol of each $\mathrm{N}$ form applied were $\mathrm{NH}_{4}-\mathrm{N}-0.6678,-0.6143$, and -0.8123 ; $\mathrm{NO}_{3}-\mathrm{N} 0.0713,0.2746$, and -0.1296 ; and urea-N $-0.2038,-0.1445$, -and 0.2711 for impatiens, petunia, and pelargonium, respectively. The parameters for meq of acidity or basicity per mmol showed that $\mathrm{NH}_{4}-\mathrm{N}$ tended to be strongly acidic, urea-N somewhat acidic, and $\mathrm{NO}_{3}-\mathrm{N}$ weakly basic to slightly acidic. Parameter values were generally in line with expected effects of $\mathrm{N}$ forms on substrate $\mathrm{pH}$. However, the pelargonium parameter for $\mathrm{NO}_{3}-\mathrm{N}$ was slightly negative, indicating acidity even with $\mathrm{NO}_{3}-\mathrm{N}$ as the sole $\mathrm{N}$ source, presumably because of the acidic effect of other cations such as calcium, magnesium, and potassium or from a greater overall tendency for pelargonium to acidify the root zone. Strong acidification of $\mathrm{NH}_{4}-\mathrm{N}$ could occur from both the charge balance effects of cation uptake by plant roots and nitrification by soil microbes with uptake of $\mathrm{NH}_{4}-\mathrm{N}$ favored over other $\mathrm{N}$ forms (Engels and Marschner, 1995; Lang and Elliott, 1991; von Wiren et al., 2001). Acidification from urea-N occurs through the net effect of hydrolysis (basic), nitrification (acidic), and nitrate uptake (basic) processes (Verburg et al., 2003). Basic effects of $\mathrm{NO}_{3}-\mathrm{N}$ occur through the charge balance effect (exudation of a base) from anion uptake by plant roots (Argo and Biernbaum, 1997; Marschner, 
1995). The need for species-specific parameters resulted from an observed difference in substrate $\mathrm{pH}$ in the order from pelargonium (lowest $\mathrm{pH}$ ), to impatiens, to petunia (highest $\mathrm{pH}$ ) when grown using a WSF at a given $\mathrm{NH}_{4}{ }^{+}: \mathrm{NO}_{3}{ }^{-}$:urea-N ratio.

Using these parameters, the CCE of fertilizer acidity or basicity could be calculated for soilless production with WSF using a simple "N CCE" formula based on $\mathrm{N}$ form, $\mathrm{N}$ concentration, and plant species. The N CCE therefore provides an alternative to the potential acidity or basicity calculations from Pierre (1933), which are widely used in the horticultural industry but which were calibrated to field soils and solid fertilizer application.

The predicted acidity or basicity of a WSF $\left(C C E_{W S F}\right.$, in units of meq of acidity or basicity, with negative values indicating acidity and positive values indicating basicity) is calculated as

$$
\begin{aligned}
\mathrm{CCE}_{\mathrm{WSF}}= & \left(\mathrm{P}_{\mathrm{NH} 4 . \mathrm{S}} * \text { meq } \mathrm{NH}_{4}-\mathrm{N}\right. \\
& +\mathrm{P}_{\mathrm{NO} 3 . \mathrm{S}} * \text { meq } \mathrm{NO}_{3}-\mathrm{N} \\
& \left.+\mathrm{P}_{\text {Urea. }} * \text { meq urea-N }\right)
\end{aligned}
$$

where $\mathrm{P}_{\mathrm{NH} 4 . \mathrm{S}}$ is a species-specific parameter with units of meq of acidity or basicity per meq of $\mathrm{NH}_{4}-\mathrm{N}$, and $\mathrm{P}_{\mathrm{NO} 3 . \mathrm{S}}$ and $\mathrm{P}_{\text {Urea.S }}$ are species-specific parameters for $\mathrm{NO}_{3}-\mathrm{N}$ and urea-N, respectively. Milliequivalents of $\mathrm{N}$ for each $\mathrm{N}$ form are calculated as $\mathrm{mg} \cdot \mathrm{L}^{-1} \mathrm{~N}$ divided by the atomic weight of 14 . The predicted acidity or basicity of a FS $\left(\mathrm{CCE}_{\mathrm{NS}}\right)$ represents the combination of the $\mathrm{CCE}_{\mathrm{WSF}}$ and the alkalinity of the water source $\left(\mathrm{CCE}_{\mathrm{IWS}}\right)$ :

$$
\mathrm{CCE}_{\mathrm{FS}}=\mathrm{CCE}_{\mathrm{WSF}}+\mathrm{CCE}_{\mathrm{IWS}}
$$

For example, consider a WSF that provides $40 \mathrm{mg} \cdot \mathrm{L}^{-1} \mathrm{~N}$ from $\mathrm{NH}_{4}-\mathrm{N}$, and $60 \mathrm{mg} \cdot \mathrm{L}^{-1} \mathrm{~N}$ from $\mathrm{NO}_{3}-\mathrm{N}$, equaling 2.9 and 4.3 meq $\mathrm{N}$ from each $\mathrm{N}$ form, respectively (which corresponds with the "Acidic WSF" in Table 1). Parameter values (negative values assigned for acidity, positive values for basicity) from Johnson et al. (2013) for pelargonium were $\mathrm{P}_{\mathrm{NH} 4 . \mathrm{S}}=-0.8123$ meq of acidity per meq $\mathrm{N}$ from $\mathrm{NH}_{4}-\mathrm{N}$ and $\mathrm{P}_{\mathrm{NO} 3 . \mathrm{S}}=-0.1296 \mathrm{meq}$ of acidity per meq $\mathrm{N}$ from $\mathrm{NO}_{3}-\mathrm{N}$. From Eq. [1], the $\mathrm{CCE}_{\mathrm{WSF}}$ therefore equals $-0.8123 * 2.9+$ $-0.1296 * 4.3=-2.3+-0.6=-2.9 \mathrm{meq}$ of acidity per liter of WSF. The irrigation water had $130 \mathrm{mg} \cdot \mathrm{L}^{-1} \mathrm{CaCO}_{3}$ of alkalinity, which divided by $50 \mathrm{mg} \cdot \mathrm{L}^{-1} \mathrm{CaCO}_{3}$ per meq equals 2.6 meq of base. The net acidity or basicity of the FS $\left(\mathrm{CCE}_{\mathrm{FS}}\right)$ from Eq. [2] for the Acidic WSF with pelargonium therefore equaled $-2.9+2.6=-0.3$ meq of acidity. This excess acidity (a negative $\mathrm{CCE}_{\mathrm{FS}}$ ) would expect to lead to a decrease in substrate $\mathrm{pH}$ over time, whereas an excess of basicity of a FS (for example, the positive $\mathrm{CCE}_{\mathrm{FS}}$ for petunia in combination with the basic FS in Table 1) would be expected to increase substrate $\mathrm{pH}$ over time. Increasingly negative or positive $\mathrm{CCE}_{\mathrm{FS}}$ indicates greater expected acidic or negative effects of the FS.

Although the N CCE model from Johnson et al. (2013) is a promising tool to assist growers in WSF selection, further validation is required. The objective of this study was to evaluate whether the N CCE model correctly predicted the trend in $\mathrm{pH}$ change under a range of conditions typically found in horticulture production. The first experiment focused on the effect of plant species at one $\mathrm{N}$ concentration and water alkalinity, where impatiens, petunia, and pelargonium, along with six other bedding plant species, were grown with WSF that had $\mathrm{NH}_{4}{ }^{+}: \mathrm{NO}_{3}{ }^{-}$ratios of $40: 60$, 20:80, or 3:97 at $100 \mathrm{mg} \cdot \mathrm{L}^{-1} \mathrm{~N}$. A second experiment focused on the effect of $\mathrm{N}$ concentration and water alkalinity with impatiens only with 50 to $200 \mathrm{mg} \cdot \mathrm{L}^{-1} \mathrm{~N}$ concentrations, $\mathrm{NH}_{4}{ }^{+}: \mathrm{NO}_{3}{ }^{-}$ratios of $75: 25$ or $3: 97$, and water alkalinity at 0 to 136 $\mathrm{mg} \cdot \mathrm{L}^{-1} \mathrm{CaCO}_{3}$.

\section{Materials and Methods}

Plant species experiment. This experiment included 27 treatments composed of three nutrient solutions and nine species in a factorial design with three replicate cell trays per treatment combination completely randomized on a greenhouse bench and six destructive samples per replicate tray over time. The substrate used was (by volume) $70 \%$ Canadian sphagnum peat (Fisons professional black bale peat; Sun Gro Horticulture, Bellevue, WA) with long fibers and little dust (Von Post scale 1 to 2; Puustjarvi and Robertson, 1975) and 30\% perlite. A dolomitic hydrated lime $\left[97 \% \mathrm{Ca}(\mathrm{OH})_{2} \cdot \mathrm{MgO}\right.$, $92 \%$ of which passed through a $45-\mu \mathrm{m}$ screen, with reported acid neutralizing value of 161\% CCE; National Lime and Stone, Findlay, $\mathrm{OH}$ ] was added at $1.5 \mathrm{~kg} \cdot \mathrm{m}^{-3}$. The lime type is an important aspect of the methodology, because the hydrated lime used is highly reactive and would not provide residual buffering to $\mathrm{pH}$ change during plant growth (Huang et al., 2010). In addition, 0.4 $\mathrm{kg}$ each of $\mathrm{KNO}_{3}$ and gypsum, $0.1 \mathrm{~kg}$ triple superphosphate $(0 \mathrm{~N}-19.8 \mathrm{P}-0 \mathrm{~K})$ and $0.07 \mathrm{~kg}$ fritted trace elements (FTE 555; Scotts, Marysville, $\mathrm{OH}$ ) per $\mathrm{m}^{3}$ of substrate were added at mixing. Sufficient reverse osmosis (RO) purified water was added at mixing to bring the moisture content of the substrate to $40 \%$ to $50 \%$ of container capacity, and the substrate was allowed to equilibrate for $3 \mathrm{~d}$ before planting. At planting, the substrate had a $\mathrm{pH}$ of 5.9, an electrical conductivity (EC) of 1.3 $\mathrm{dS} \cdot \mathrm{m}^{-1}$, and (in $\mathrm{mg} \cdot \mathrm{L}^{-1}$ ) $75 \mathrm{NO}_{3}-\mathrm{N}, 20$ phosphorus (P), 110 potassium (K), 105 calcium $(\mathrm{Ca}), 55$ magnesium $(\mathrm{Mg})$, and $60 \mathrm{SO}_{4}$-S based on the saturated media extract (Warncke, 1986).

Table 1. Total macronutrient concentrations of the nutrient solutions used in the two experiments resulting from different water-soluble fertilizers (WSFs) and

\begin{tabular}{|c|c|c|c|c|c|c|c|c|c|c|c|}
\hline Alkalinity and & itration & & & & & & & & $50 \mathrm{mg} \cdot \mathrm{L}^{-1} \mathrm{~N}$ & $100 \mathrm{mg} \cdot \mathrm{L}^{-1} \mathrm{~N}$ & $200 \mathrm{mg} \cdot \mathrm{L}^{-1} \mathrm{~N}$ \\
\hline Basic $\mathrm{WSF}^{\mathrm{w}}$ & 0 & 3 & 97 & 13 & 87 & 62 & 23 & 1 & 0.2 & 0.4 & 0.7 \\
\hline Acidic $\mathrm{WSF}^{\mathrm{u}}$ & 136 & 75 & 28 & 13 & 73 & 52 & 11 & 25 & 1.0 & -0.7 & -4.2 \\
\hline Basic $\mathrm{WSF}^{\mathrm{t}}$ & 136 & 3 & 100 & 13 & 94 & 114 & 34 & 25 & 2.9 & 3.1 & 3.4 \\
\hline
\end{tabular}
water sources. ${ }^{z}$

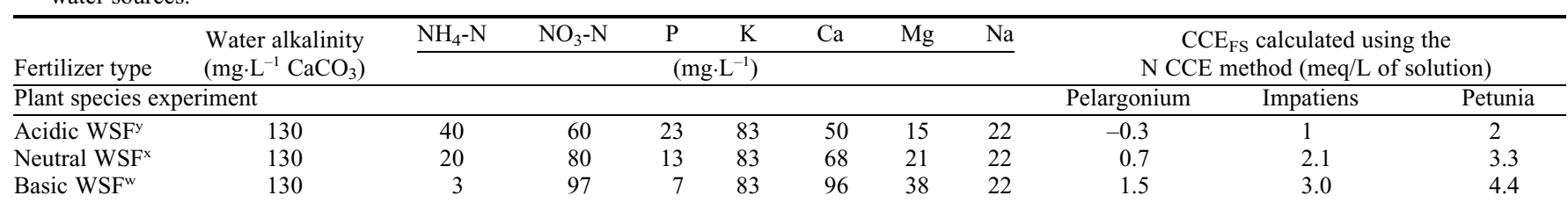

Alkalinity and $\mathrm{N}$ concentration experiment ${ }^{\mathrm{t}}$

${ }^{2}$ In the plant species experiment, the solution was applied at $100 \mathrm{mg} \cdot \mathrm{L}^{-1}$ nitrogen $(\mathrm{N})$ only, whereas in the alkalinity and $\mathrm{N}$ concentration experiment, the solution was applied at 50,100 , and $200 \mathrm{mg} \cdot \mathrm{L}^{-1} \mathrm{~N}$. The expected potential fertilizer acidity or basicity $\left(\mathrm{CCE}_{\mathrm{FS}}\right)$ was calculated using the $\mathrm{N}$ calcium carbonate equivalent (CCE) method (Johnson et al., 2013).

${ }_{2} 20 \mathrm{~N}-4.3 \mathrm{P}-16.6 \mathrm{~K}-0 \mathrm{Ca}-0 \mathrm{Mg}$ Peatlite Special (macronutrients derived from $\mathrm{KNO}_{3}, \mathrm{NH}_{4} \mathrm{H}_{2} \mathrm{PO}_{4}$, and $\mathrm{NH}_{4} \mathrm{NO}_{3}$ ) mixed with a blend of reverse osmosis and well water.

${ }^{\mathrm{x}} 17 \mathrm{~N}-2.2 \mathrm{P}-14.1 \mathrm{~K}-3 \mathrm{Ca}-1 \mathrm{Mg}$ [macronutrients derived from $5 \mathrm{Ca}\left(\mathrm{NO}_{3}\right)_{2}, \mathrm{NH}_{4} \mathrm{NO}_{3} \cdot 10 \mathrm{H}_{2} \mathrm{O}, \mathrm{KNO}_{3}, \mathrm{Mg}\left(\mathrm{NO}_{3}\right)_{2} \cdot 6 \mathrm{H}_{2} \mathrm{O}, \mathrm{NH}_{4} \mathrm{H}_{2} \mathrm{PO}_{4}$, and $\mathrm{NH}_{4} \mathrm{NO}_{3}$ ] mixed with a blend of reverse osmosis and well water.

${ }^{w} 13 \mathrm{~N}-0.9 \mathrm{P}-10.8 \mathrm{~K}-6 \mathrm{Ca}-3 \mathrm{Mg}$ [macronutrients derived from $5 \mathrm{Ca}\left(\mathrm{NO}_{3}\right)_{2}, \mathrm{NH}_{4} \mathrm{NO}_{3} \cdot 10 \mathrm{H}_{2} \mathrm{O}, \mathrm{KNO}_{3}, \mathrm{Mg}\left(\mathrm{NO}_{3}\right)_{2} \cdot 6 \mathrm{H}_{2} \mathrm{O}$, and $\mathrm{NH}_{4} \mathrm{H}_{2} \mathrm{PO}_{4}$ ] mixed with a blend of reverse osmosis and well water.

v $17.6 \mathrm{~N}-2.2 \mathrm{P}-10.9 \mathrm{~K}-0 \mathrm{Ca}-0 \mathrm{Mg}$ [macronutrients derived from $\mathrm{KCl}, \mathrm{NH}_{4} \mathrm{NO}_{3}, \mathrm{NH}_{4} \mathrm{H}_{2} \mathrm{PO}_{4}$, and $\left(\mathrm{NH}_{4}\right)_{2} \mathrm{SO}_{4}$ ] mixed with either reverse deionized or well water. ${ }^{u} 12.6 \mathrm{~N}-1.3 \mathrm{P}-10.0 \mathrm{~K}-7.72 \mathrm{Ca}-2.82 \mathrm{Mg}$ [macronutrients derived from $5 \mathrm{Ca}\left(\mathrm{NO}_{3}\right)_{2}, \mathrm{NH}_{4} \mathrm{NO}_{3} \cdot 10 \mathrm{H}_{2} \mathrm{O}, \mathrm{KNO}_{3}, \mathrm{KH}_{2} \mathrm{PO}_{4}$, and $\left.\left.\mathrm{Mg}\left(\mathrm{NO}_{3}\right)_{2} \cdot 6 \mathrm{H}_{2} \mathrm{O}\right)\right]$ mixed with either reverse deionized or well water.

${ }^{\text {t}}$ Total concentrations of nutrient solutions are shown at $100 \mathrm{mg} \cdot \mathrm{L}^{-1} \mathrm{~N}$, but treatments also included 50 and $200 \mathrm{mg} \cdot \mathrm{L}^{-1} \mathrm{~N}$. 
The three nutrient solutions varied in the $\mathrm{NH}_{4}{ }^{+}: \mathrm{NO}_{3}{ }^{-}$ratio, $\mathrm{P}, \mathrm{Ca}$, and $\mathrm{Mg}$ concentrations, but were applied at a constant 100 $\mathrm{mg} \cdot \mathrm{L}^{-1} \mathrm{~N}$. The three commercially available WSF were 1) acidic WSF with (in percent of total mass) $20 \mathrm{~N}-4.3 \mathrm{P}-16.6 \mathrm{~K}-0 \mathrm{Ca}-0 \mathrm{Mg}$, which had an $\mathrm{NH}_{4}{ }^{+}: \mathrm{NO}_{3}{ }^{-}$ratio of $40: 60$ and a potential acidity using the industry standard Pierre's Method (Pierre, 1933) of 200 $\mathrm{kg} / 1000 \mathrm{~kg}$ of fertilizer; 2) neutral WSF with $17 \mathrm{~N}-2.2 \mathrm{P}-14.1 \mathrm{~K}-3 \mathrm{Ca}-1 \mathrm{Mg}$ with an $\mathrm{NH}_{4}{ }^{+}$: $\mathrm{NO}_{3}{ }^{-}$ratio of $25: 75$ and a potential acidity of $0 \mathrm{~kg} / 1000 \mathrm{~kg}$ of fertilizer; and 3) basic WSF with $13 \mathrm{~N}, 0.9 \mathrm{P}, 10.8 \mathrm{~K}, 6 \mathrm{Ca}, 3 \mathrm{Mg}$ with an $\mathrm{NH}_{4}{ }^{+}: \mathrm{NO}_{3}{ }^{-}$ratio of $4: 96$ and a potential basicity of $150 \mathrm{~kg} / 1000 \mathrm{~kg}$ of fertilizer (Greencare Fertilizers, Chicago, IL). Micronutrients were applied in all solutions (in $\left.\mathrm{mg} \cdot \mathrm{L}^{-1}\right)$ at 0.5 iron $(\mathrm{Fe}), 0.25$ manganese $(\mathrm{Mn}), 0.25$ zinc $(\mathrm{Zn}), 0.125$ copper $(\mathrm{Cu})$, 0.125 boron (B), and 0.05 molybdenum (Mo) from Fe-EDTA, Mn-EDTA, Zn-EDTA, $\mathrm{Cu}$-EDTA, boric acid, and sodium molybdate for the acidic WSF or from Fe-EDTA, $\mathrm{MnSO}_{4}$, $\mathrm{ZnSO}_{4}, \mathrm{CuSO}_{4}$, boric acid, and sodium molybdate for the other two WSFs. The WSF were mixed with a blend of well and RO water ( $1: 1.5$ by volume) that had a $\mathrm{pH}$ of 6.7 , an $\mathrm{EC}$ of 0.3 $\mathrm{dS} \cdot \mathrm{m}^{-1}, 50 \mathrm{Ca}^{2+}, 15 \mathrm{Mg}^{2+}, 25 \mathrm{Na}^{+}$, and 10 $\mathrm{SO}_{4}-\mathrm{S}^{2-}\left(\mathrm{mg} \cdot \mathrm{L}^{-1}\right)$; and a titratable alkalinity to $\mathrm{pH} 4.5$ of $130 \mathrm{mg} \cdot \mathrm{L}^{-1} \mathrm{CaCO}_{3}$. The total macronutrient concentration of the three FS applied at every irrigation is found in Table 1 .

The experiment was conducted starting on 6 Mar. 1996 at Michigan State University, East Lansing, MI, in a well-ventilated glass greenhouse with constant air circulation and cement floors. The bedding plant species tested were pelargonium 'Orbit Hot Pink', bedding plant impatiens 'Super Elfin Violet', Tagetes patula L. 'Bonanza Yellow' (marigold), Begonia tuberhybrida Voss 'Nonstop Pink' (tuberous begonia), Viola $\times$ wittrockiana Gams 'Orange Crown' (pansy), petunia 'Flash Rose', Salvia splendens Sellow ex Schult. 'Sizzler Lavender' (salvia), Vinca rosea L. 'Little Bright Eyes' (vinca), and Begonia semperflorens Hook. 'Vodka' (wax begonia). Plugs from a 512 tray (288 tray for pelargonium) were planted into 1204 (0.07 L per cell) bedding plant flats containing the peat/perlite substrate. Plants in each flat were irrigated as needed with $0.5 \mathrm{~L}$ of one of the three FS using a small sprinkling can for uniform distribution with less than 5\% leaching fraction.

Substrate samples were destructively collected from one cell per flat (three per treatment, randomly selected) at $0,3,7,14,21$, and $28 \mathrm{~d}$ after planting. Substrate $\mathrm{pH}$ was tested by preparing a sample using the 1:2 method (Biernbaum et al., 1993) followed by inserting the electrodes directly into the slurry.

The predicted $\mathrm{pH}$ effect in terms of the $\mathrm{CCE}_{\mathrm{FS}}$ of each FS (shown in Table 1) was calculated using Eqs. [1] and [2] from the meq of acidity or basicity of the fertilizer for impatiens, petunia, and pelargonium using the N CCE model (Johnson et al., 2013) plus the alkalinity of the water source.

Substrate $\mathrm{pH}$ data were subjected to analysis of variance (ANOVA) using PROC
GLIMMIX (SAS Institute, Cary, NC) as a 9 $\times 3$ factorial at each sampling date. Time was not included in the ANOVA because sample variance changed over time. The relationship between change in substrate $\mathrm{pH}$ from the beginning to the end of the experiment (on Day 28) vs. CCE $E_{F S}$ was tested for the three FS and three species with model parameters (impatiens, pelargonium, and petunia). To analyze this relationship, ANCOVA in PROC GLM treated species as a class variable and $\mathrm{CCE}_{\mathrm{FS}}$ as a continuous variable, change in measured $\mathrm{pH}$ was the dependent variable, and the tested effects included $\mathrm{CCE}_{\mathrm{FS}}$, species, and $\mathrm{CCE}_{\mathrm{FS}}{ }^{*}$ species.

Alkalinity and $N$ concentration experiment. The experiment was conducted in a computercontrolled polycarbonate greenhouse at the University of Florida in Gainesville, FL, starting on 12 Mar. 2012. The factorial design included two WSFs $\times$ two water sources $\times$ three $\mathrm{N}$ concentrations using one cultivar (impatiens 'Super Elfin Red'). The fertilizer types were an acidic reaction fertilizer $17.6 \mathrm{~N}-2.2 \mathrm{P}-10.9 \mathrm{~K}-0 \mathrm{Ca}-0 \mathrm{Mg}\left(75 \% \mathrm{NH}_{4}-\mathrm{N}\right.$, $\left.25 \% \mathrm{NO}_{3}-\mathrm{N}\right)$ and a basic reaction fertilizer $12.6 \mathrm{~N}-1.3 \mathrm{P}-10.0\left(3 \% \mathrm{NH}_{4}-\mathrm{N}, 97 \% \mathrm{NO}_{3}-\mathrm{N}\right)$ (Greencare Fertilizers, Kankakee, IL). Complete macronutrient analysis is shown in Table 1 in combination with the water sources. The two water sources were deionized water ["DI water," zero alkalinity with (in $\mathrm{mg} \cdot \mathrm{L}^{-1}$ ) $0.0-\mathrm{NO}_{3}-\mathrm{N} 0.0 \mathrm{P}, 0.4 \mathrm{~K}, 0.6 \mathrm{Ca}, 0.4 \mathrm{Mg}, 0.9$ sulfur (S), 0.3 Fe, $0.01 \mathrm{Mn}, 0.01 \mathrm{Zn}, 0.07 \mathrm{Cu}$, $0.10 \mathrm{~B}$, and $0.05 \mathrm{Mo})]$ and well water $[135.5$ $\mathrm{CaCO}_{3}$ or 2.7 meq alkalinity, with (in mg. $\mathrm{L}^{-1}$ ) $2.8-\mathrm{NO}_{3}-\mathrm{N} 0.0 \mathrm{P}, 11.1 \mathrm{~K}, 52.4 \mathrm{Ca}, 11.1 \mathrm{Mg}$, 34.7 S, 0.3 Fe, 0.01 Mn, 0.01 Zn, $0.07 \mathrm{Cu}$, $0.10 \mathrm{~B}$, and $0.05 \mathrm{Mo}$. Applied fertilizer $\mathrm{N}$ concentrations were 50,100 , and $200 \mathrm{mg} \cdot \mathrm{L}^{-1}$ $\mathrm{N}$. With all solutions, micronutrients were added (in $\mathrm{mg} \cdot \mathrm{L}^{-1}$ ) at $1.0 \mathrm{Fe}, 0.5 \mathrm{Mn}, 0.5$ $\mathrm{Zn}, 0.25 \mathrm{Cu}, 0.25 \mathrm{~B}$, and $0.05 \mathrm{Mo}$ from Fe-EDDHA, $\mathrm{MnSO}_{4}, \mathrm{ZnSO}_{4}, \mathrm{CuSO}_{4}$, boric acid, and sodium molybdate. Each combination of fertilizer type, alkalinity, and fertilizer concentration had 27 replications $(10-\mathrm{cm}$ diameter, $385-\mathrm{mL}$ pots) organized in three blocks with nine replicate pots per fertilizer type*alkalinity* $\mathrm{N}$ concentration treatment completely randomized within each block.

A 70 peat: 30 perlite (by volume) substrate was mixed with dolomitic hydrated limestone $\left[97 \% \mathrm{Ca}(\mathrm{OH})_{2} \cdot \mathrm{MgO}, 92 \%\right.$ of which passed through a $45-\mu \mathrm{m}$ screen with reported acid neutralizing value of $161 \% \mathrm{CCE}$; $\mathrm{Na}-$ tional Lime and Stone, Findlay, $\mathrm{OH}$ ] at 2.01 $\mathrm{kg} \cdot \mathrm{m}^{-3}$ to raise substrate $\mathrm{pH}$ to $\approx 6.0$. No other pre-plant fertilizer charge was applied. The peat source used in the research substrates was Canadian Sphagnum peat (Sun Gro Horticulture, Vancouver, Canada) with long fibers and little dust (von Post scale 1 to 2; Puustjarvi and Robertson, 1975).

After transplanting, the plants were grown for 2 weeks before the treatments began. During this time, plants were irrigated with $50 \mathrm{mg} \cdot \mathrm{L}^{-1} \mathrm{~N}$ with the neutral FS from the Plant Species Experiment. Because there was no pre-plant nutrient charge in this experiment, in contrast to the Plant Species Experiment, the 2-week transition period allowed the WSF to react with the substrate cation exchange capacity to provide a stable $\mathrm{pH}$. After the 2-week pre-treatment, the substrate $\mathrm{pH}$ and EC of $5.60 \pm 0.04$ and $0.85 \pm 0.09 \mathrm{dS} \cdot \mathrm{m}^{-1}$ (mean $\pm \mathrm{SE}$ ), respectively, were determined using the saturated medium extract with six replicate samples (Warncke, 1986). Saucers were placed under each pot to allow reabsorption of any leachate. After 5 weeks of treatment, and application of $2 \mathrm{~L}$ per pot of irrigation solution, four replicates per block (total of 12 plants per fertilizer * $\mathrm{N}$ concentration * water source treatment combination) were sampled for substrate $\mathrm{pH}$ and EC using the saturated medium extract method. At this final stage, plants all appeared healthy and in full bloom.

Substrate $\mathrm{pH}$ and EC data at Week 5 were subjected to ANOVA using PROC GLIMMIX (SAS Institute) as a $2 \times 2 \times 3$ factorial. The predicted $\mathrm{pH}$ effect of each $\mathrm{FS}\left(\mathrm{CCE}_{\mathrm{FS}}\right)$ was calculated from the meq of acidity or basicity of the fertilizer for impatiens using the $\mathrm{N}$ CCE model plus the alkalinity of the water source. The mean change in substrate $\mathrm{pH}$ from the beginning to the end of the experiment (Day 35) for each FS was compared with $\mathrm{CCE}_{\mathrm{FS}}$ using simple linear regression. The model was also validated using analysis of covariance (ANCOVA) in PROC GLM, which treated $\mathrm{N}$ concentration and water alkalinity as class variables and $\mathrm{CCE}_{\mathrm{Fs}}$ as a continuous variable, change in measured $\mathrm{pH}$ was the dependent variable, and the tested effects included $\mathrm{CCE}_{\mathrm{FS}}, \mathrm{N}$ concentration, water alkalinity, and their interactions.

\section{Results and Discussion}

Plant species experiment. Results for ANOVA from Days 3, 7, 14, 21, and 28, analyzed separately by day (Table 2 ), showed a significant main effect of plant species on each measurement day, the main effect of WSF from Day 14 onward, and no interaction between plant species and WSF on any measurement day. Between planting and Day 7 , substrate $\mathrm{pH}$ was similar for all treatments (Table 2) with a pH range of only 6.13 to 6.29 on Day 3 and 6.13 to 6.43 by Day 7. Argo and Biernbaum $(1996,1997)$ similarly found that the FS had minimal effect on substrate $\mathrm{pH}$ up to 4 weeks after planting in larger size containers $(0.75$ L). Fisher et al. (2014) showed that ammonium and nitrate had weak impacts on substrate $\mathrm{pH}$ in a peat-perlite substrate in the absence of plants, which is similar to the situation when plant root systems are small relative to the substrate volume.

From Day 14 onward, both the WSF and plant species affected substrate $\mathrm{pH}$ (Table 2). There was a significant difference between the $\mathrm{pH}$ level of each FS at Day 28 with a least-square mean of $6.04,6.42$, or 6.86 with the acidic, neutral, or basic WSF, respectively. Least-square mean $\mathrm{pH}$ by Day 28 ranged between species from 5.69 to 6.72 with pelargonium having a lower $\mathrm{pH}$ than all other species, regardless of the WSF that was 
applied. In comparison, the other species maintained their substrate $\mathrm{pH}$ up to $1 \mathrm{pH}$ unit higher than pelargonium. Marigold is considered an Fe-efficient species (Albano and Miller, 1996) and along with wax begonia had a lower $\mathrm{pH}$ than pansy, which is considered $\mathrm{Fe}$-inefficient and susceptible to $\mathrm{Fe}$ deficiency at high $\mathrm{pH}$ (Argo and Fisher, 2002).

Bailey et al. (1996) suggested that the same WSF should not be used on all species, because plant species differ in their target substrate $\mathrm{pH}$ ranges and tendency to raise or lower $\mathrm{pH}$. However, it may be impractical to use different WSF on bedding plant species being grown in the same greenhouse. An alternative method for optimizing $\mathrm{pH}$ management using the same WSF may be to use two or more substrates with different limestone rates and starting $\mathrm{pH}$ values. For example, species that tend to decrease substrate $\mathrm{pH}$ (such as pelargonium) can be planted into a substrate with a starting $\mathrm{pH}$ greater than 6.0. In contrast, species that tend to increase $\mathrm{pH}$ (such as pansy or petunia) could be planted into a substrate with a starting $\mathrm{pH}$ less than 5.8.

The change in substrate $\mathrm{pH}$ from Day 0 to Day 28 was compared with the acidity or basicity of each WSF as predicted by both the $\mathrm{CCE}_{\mathrm{FS}}$ (continuous variable) and plant species (class variable) using ANCOVA. The change in $\mathrm{pH}$ was affected by the $\mathrm{CCE}_{\mathrm{FS}}(P<$ $0.0001)$ but not by species or the interaction between $\mathrm{CCE}_{\mathrm{FS}}$ and species. The linear relationship between $\mathrm{CCE}_{\mathrm{FS}}$ and change in substrate $\mathrm{pH}$ is shown in Figure 1, whereby the more basic the $\mathrm{CCE}_{\mathrm{FS}}$, the higher substrate $\mathrm{pH}$ after $28 \mathrm{~d}$. The only WSF predicted to have a negative (acidic) $\mathrm{CCE}_{\mathrm{FS}}$ was the acidic WSF in combination with pelargonium (Table 1), and this was the only treatment combination in which substrate $\mathrm{pH}$ decreased over time. The observed trend lends confidence to the N CCE method when selecting a WSF for a given species to achieve a stable substrate $\mathrm{pH}$ using an alkaline water source, whereas the model was calibrated using DI water (Johnson et al., 2013). However, although the model had a high adjusted $R^{2}$ of 0.849 and high level of statistical significance, the N CCE slightly underpredicted the observed acidity of FS overall for this experiment. The regression line in Figure 1 shows this bias, whereby an estimated N CCE of $0.94 \mathrm{meq} \quad(=0.411$ intercept $/ 0.438$ gradient) would be expected to have a neutral $\mathrm{pH}$ effect in this trial.

Alkalinity and $N$ concentration experiment. Results from the ANOVA of effects of WSF, $\mathrm{N}$ concentration, and water alkalinity on substrate $\mathrm{pH}$ (Table 3 ) found main effects were significant for each factor, but there were no significant interactions. Basic WSF resulted in a higher $\mathrm{pH}$ (6.01) than acidic WSF (5.22). Water alkalinity increased substrate $\mathrm{pH}$ from 5.28 with DI water to 5.95 with alkaline water. Increasing $\mathrm{N}$ concentration decreased $\mathrm{pH}$ with a trend in $\mathrm{pH}$ of 5.74, 5.68 , or 5.43 with 50,100 , or $200 \mathrm{mg} \cdot \mathrm{L}^{-1} \mathrm{~N}$, respectively. The $\mathrm{pH}$ trends with WSF and water alkalinity were expected. However, ANOVA results indicate that increasing the concentration of not only the acidic WSF, but also the basic WSF, decreased substrate $\mathrm{pH}$. A decreasing $\mathrm{pH}$ with increased concentration of a basic WSF is contrary to the trend expected using the N CCE model (and also Pierre's method (Pierre, 1933). Our hypothesis for why $\mathrm{pH}$ was slightly lower $\mathrm{pH}$ as the $\mathrm{N}$ concentration of the basic WSF increased is that $\mathrm{Ca}$ and $\mathrm{Mg}$ in the basic WSF, which were higher than in the acidic WSF (Table 1), may have decreased substrate $\mathrm{pH}$ because of an interaction with exchange sites on the peat. Fisher et al. (2014) showed (in the absence of plants) that increasing concentration of $\mathrm{Ca}$ and $\mathrm{Mg}$ in a FS caused a decrease in $\mathrm{pH}$ of a peat-perlite substrate because of displacement of protons through cation exchange.

The relationship between final substrate EC and the nutrient solutions was complex, and substrate EC ranged widely between treatments (Table 3). The ANOVA of effects of WSF, N concentration, water alkalinity, and their interactions on substrate EC found

all main and interaction effects were significant other than the interaction between WSF and water alkalinity (for which $P=0.054$ ). In all treatment combinations, we observed healthy root and shoot tissue with heavy flower blooms despite the wide range in nutrient levels (data not shown). Substrate EC tended to increase with increasing $\mathrm{N}$ concentration with use of the acidic WSF and with alkaline water. Fisher et al. (2014) showed a trend of decreased substrate $\mathrm{pH}$ as substrate EC increased with FS that contained $\mathrm{Ca}$. Increasing the concentration of the basic fertilizer from 50 to $200 \mathrm{mg} \cdot \mathrm{L}^{-1} \mathrm{~N}$ would also increase the concentration of acidic $\mathrm{NH}_{4}-\mathrm{N}$ ions, but the $\mathrm{pH}$ effect of $\mathrm{NH}_{4}-\mathrm{N}$ would be expected to be minimal given that the concentration would only increase from 1.5 to $6 \mathrm{mg} \cdot \mathrm{L}^{-1} \mathrm{NH}_{4}-\mathrm{N}$ as $\mathrm{N}$ concentration increased from 50 to $200 \mathrm{mg} \cdot \mathrm{L}^{-1} \mathrm{~N}$.

The predicted meq of acidity or basicity using the $\mathrm{N} C \mathrm{CE}$ method $\left(\mathrm{CCE}_{\mathrm{FS}}\right)$ shown in Table 1 was more affected by the $\mathrm{N}$ concentration for the acidic WSF than for the basic

Table 2. Plant species experiment: results of analysis of variance of substrate $\mathrm{pH}$ over time for nine species grown with the three nutrient solutions detailed in Table $1 .{ }^{\mathrm{z}}$

\begin{tabular}{|c|c|c|c|c|c|}
\hline \multirow[b]{2}{*}{ Plant Species } & \multicolumn{5}{|c|}{ Day } \\
\hline & 3 & 7 & 14 & 21 & 28 \\
\hline Impatiens & $6.19 \mathrm{ab}$ & $6.32 \mathrm{abc}$ & $6.42 \mathrm{ab}$ & $6.70 \mathrm{a}$ & $6.66 \mathrm{ab}$ \\
\hline Marigold & $6.14 \mathrm{~b}$ & $6.30 \mathrm{abc}$ & $6.44 \mathrm{ab}$ & $6.22 \mathrm{bc}$ & $6.40 \mathrm{ab}$ \\
\hline Pansy & $6.21 \mathrm{ab}$ & $6.31 \mathrm{abc}$ & $6.51 \mathrm{ab}$ & $6.68 \mathrm{a}$ & $6.72 \mathrm{a}$ \\
\hline Pelargonium & $6.20 \mathrm{ab}$ & $6.13 \mathrm{c}$ & $5.92 \mathrm{c}$ & $5.90 \mathrm{c}$ & $5.69 \mathrm{c}$ \\
\hline Petunia & $6.21 \mathrm{ab}$ & $6.43 \mathrm{a}$ & $6.54 \mathrm{a}$ & $6.74 \mathrm{a}$ & $6.70 \mathrm{ab}$ \\
\hline Salvia & $6.18 \mathrm{ab}$ & $6.38 \mathrm{ab}$ & $6.51 \mathrm{ab}$ & $6.53 \mathrm{ab}$ & $6.70 \mathrm{ab}$ \\
\hline Tuberous begonia & $6.29 \mathrm{a}$ & $6.29 \mathrm{abc}$ & $6.27 \mathrm{ab}$ & $6.41 \mathrm{ab}$ & $6.36 \mathrm{ab}$ \\
\hline Vinca & $6.18 \mathrm{ab}$ & $6.23 \mathrm{abc}$ & $6.28 \mathrm{ab}$ & $6.22 \mathrm{bc}$ & $6.42 \mathrm{ab}$ \\
\hline Wax begonia & $6.13 \mathrm{~b}$ & $6.23 \mathrm{abc}$ & $6.22 \mathrm{bc}$ & $6.24 \mathrm{bc}$ & $6.32 \mathrm{~b}$ \\
\hline Acidic WSF & $6.19 \mathrm{a}$ & $6.29 \mathrm{a}$ & $6.24 \mathrm{~b}$ & $6.26 \mathrm{~b}$ & $6.04 \mathrm{c}$ \\
\hline Neutral WSF & $6.20 \mathrm{a}$ & $6.30 \mathrm{a}$ & $6.36 \mathrm{ab}$ & $6.38 \mathrm{~b}$ & $6.42 \mathrm{~b}$ \\
\hline Basic WSF & $6.19 \mathrm{a}$ & $6.28 \mathrm{a}$ & $6.44 \mathrm{a}$ & $6.58 \mathrm{a}$ & $6.86 \mathrm{a}$ \\
\hline Plant species main effect ${ }^{\mathrm{y}}$ & $*$ & $* *$ & $* * *$ & $* * *$ & $* * *$ \\
\hline WSF main effect & NS & NS & ** & $* * *$ & *** \\
\hline Plant species*WSF interaction & NS & NS & NS & NS & NS \\
\hline
\end{tabular}

${ }^{\mathrm{z}}$ Data by species represent the least-square mean of three samples and by water-soluble fertilizer (WSF) for 27 samples with mean separation using Tukey's honestly significant difference at the $\alpha=0.05$ level. ${ }^{\text {y }}$ Statistical significance at the $* P=0.05, * * 0.01$, or $* * * 0.001$ levels or nonsignificant (Ns).

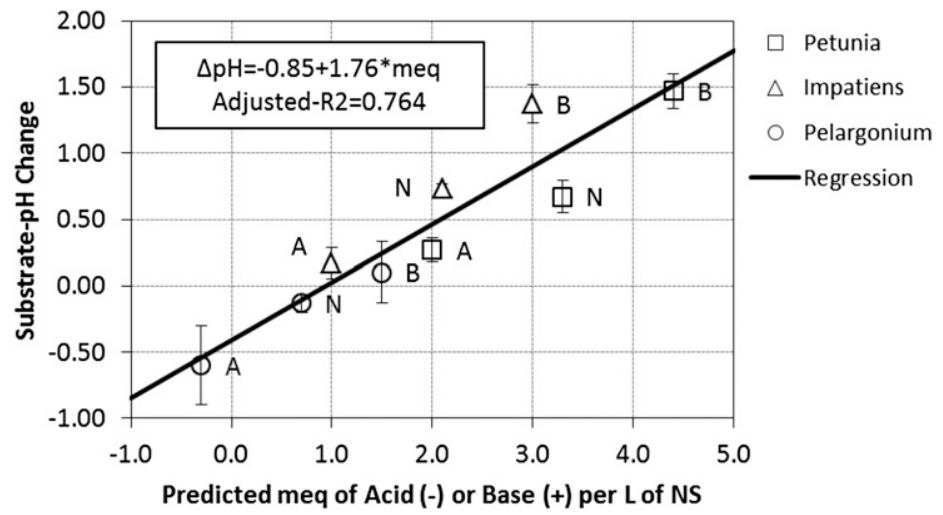

Fig. 1. Plant species experiment: comparison of change in substrate $\mathrm{pH}$ from Day 0 to 28 (negative values indicate a drop in substrate $\mathrm{pH}$ over time) with predicted milliequivalents of acid (negative values) or base (positive) of each fertilizer solution (FS) using the nitrogen calcium carbonate equivalent (CCE) calculations for pelargonium, impatiens, and petunia. The letters A, N, or B refer to the acidic, neutral, or basic reaction FS from Table 1. Symbols represent the mean of three replicates \pm 1 SE calculated separately for each treatment mean. 
Table 3. Alkalinity and nitrogen $(\mathrm{N})$ concentration experiment: analysis of variance results for effects of fertilizer type, water alkalinity, and $\mathrm{N}$ concentration on substrate $\mathrm{pH}$ and substrate-electrical conductivity (EC) at Day $35 .^{2}$

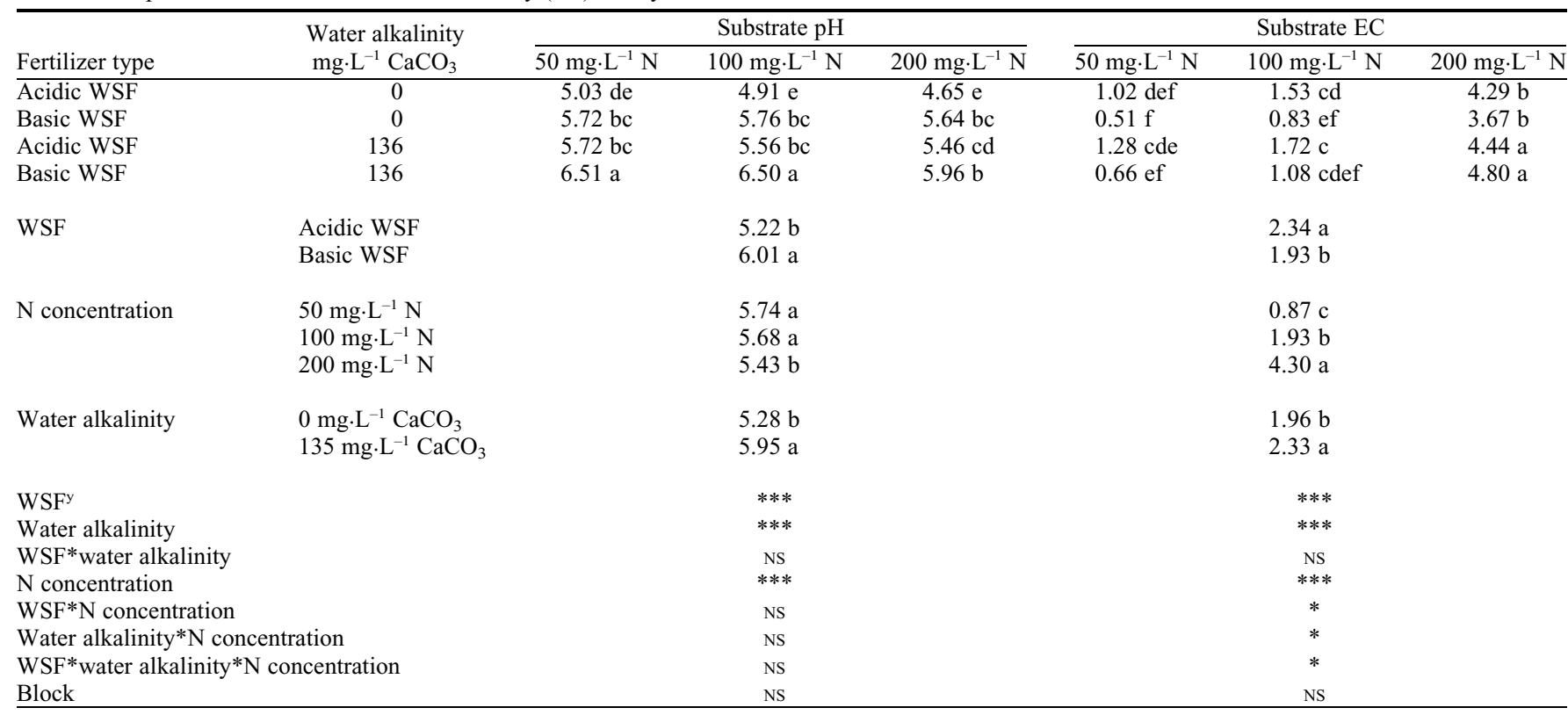

${ }^{2}$ Data by fertilizer type* water alkalinity* $\mathrm{N}$ concentration represent the least-square means of 12 samples. Mean separation for interaction and main effects was with Tukey's honestly significant difference at the $\alpha=0.05$ level.

${ }^{\mathrm{y}}$ Statistical significance at the ${ }^{*} P=0.05,{ }^{*} 0.01$, or $* * * 0.001$ levels or nonsignificant (NS).

WSF. For example, with the acidic fertilizer, predicted acidity ranged from $-1.7 \mathrm{meq}$ at 50 $\mathrm{mg} \cdot \mathrm{L}^{-1} \mathrm{~N}$ to $-6.9 \mathrm{meq}$ at $200 \mathrm{mg} \cdot \mathrm{L}^{-1} \mathrm{~N}$ in DI water compared with a range of only 0.2 to $0.7 \mathrm{meq}$ as the basic WSF increased from 50 to $200 \mathrm{mg} \cdot \mathrm{L}^{-1} \mathrm{~N}$ in DI water. These predicted ranges in meq emphasize the stronger impact of $\mathrm{NH}_{4}-\mathrm{N}$ compared with $\mathrm{NO}_{3}-\mathrm{N}$ in the $\mathrm{N}$ CCE method. The water alkalinity of 135.5 $\mathrm{mg} \cdot \mathrm{L}^{-1} \mathrm{CaCO}_{3}$ (2.7 meq) increased the predicted meq of basicity of all FS by $2.7 \mathrm{meq}$ compared with the same fertilizer type and concentration with the DI water source, because the meq of water alkalinity is simply added to the fertilizer meq in the $\mathrm{N}$ CCE method to calculate net meq of the combined water and fertilizer FS (from Eq. [2]).

The ANCOVA evaluated the effects of $\mathrm{CCE}_{\mathrm{FS}}$ (continuous variable), water alkalinity, and $\mathrm{N}$ concentration (class variables) on observed change in substrate $\mathrm{pH}$. This analysis showed a significant effect of $\mathrm{CCE}_{\mathrm{FS}}$ $(P<0.0001)$, the interaction between $\mathrm{CCE}_{\mathrm{FS}}$ and $\mathrm{N}$ concentration $(P<0.0001)$, and the interaction of water alkalinity and $\mathrm{N}$ concentration. Least-square means for each treatment combination of water alkalinity and $\mathrm{N}$ concentration are presented in Figure 2, which shows an overall trend whereby an increasingly acidic $\mathrm{CCE}_{\mathrm{FS}}$ tended to result in a greater reduction in substrate $\mathrm{pH}$ over time. The significant interactions emphasize the underlying complexity of fertilizer and water effects on substrate $\mathrm{pH}$. As indicated previously, increasing $\mathrm{N}$ concentration of the basic fertilizer did not cause the predicted increase in substrate $\mathrm{pH}$, contrary to model predictions. For a complete model of substrate $\mathrm{pH}$ change, therefore, other nutrients such as $\mathrm{Ca}$ and $\mathrm{Mg}$ and factors such as substrate cation exchange capacity need to be accounted for.

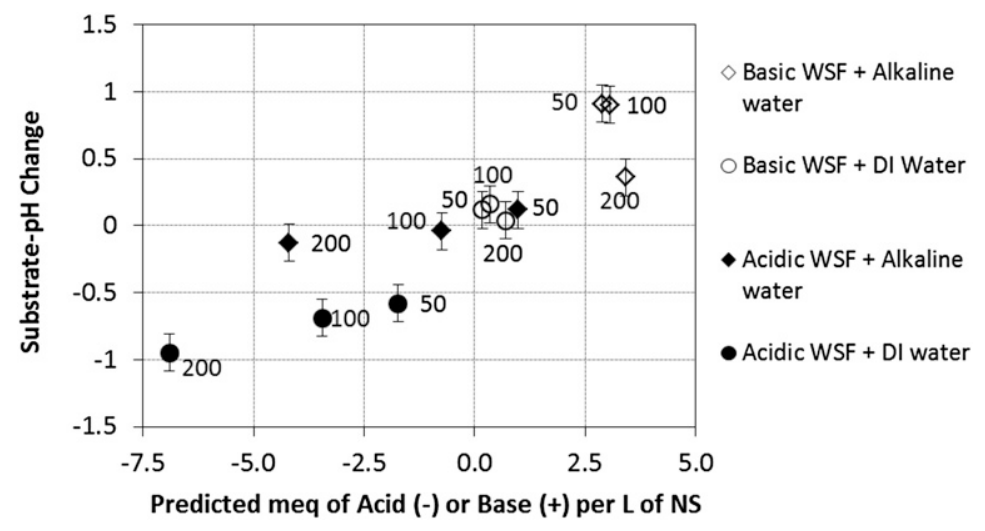

Fig. 2. Alkalinity and nitrogen $(\mathrm{N})$ concentration experiment: comparison of the change in substrate $\mathrm{pH}$ from Day 0 to Day 35 (vertical axis) with predicted meq of acid (negative values) or base (positive) of the nutrient solution (FS). Predicted milliequivalents (meq) were calculated using the $\mathrm{N}$ calcium carbonate equivalent (CCE) model for the different FS with impatiens plus the alkalinity of the irrigation water $\left(0 \mathrm{mg} \cdot \mathrm{L}^{-1} \mathrm{CaCO}_{3}\right.$ for deionized water and $136 \mathrm{mg} \cdot \mathrm{L}^{-1} \mathrm{CaCO}_{3}$ for the alkaline well water). Labels next to symbols represent the $\mathrm{mg} \cdot \mathrm{L}^{-1} \mathrm{~N}$. Symbols represent the least-square mean of 12 replicates $\pm 1 \mathrm{SE}$ calculated from the residual mean square from the analysis of covariance.

\section{Conclusion}

In the production of container-grown crops, it is not environmentally or economically acceptable to manage $\mathrm{pH}$ and nutrient concentrations in the substrate and plant tissue with high WSF concentrations and high leaching rates (Biernbaum, 1992). Irrigation systems that minimize or eliminate water and fertilizer runoff into the environment are widely available. Optimizing $\mathrm{pH}$ management in lowor non-leaching irrigation systems requires an understanding of how a variety of factors, including the plant species, WSF, and water alkalinity, interact during production.

The results provide confidence for the $\mathrm{N}$ $\mathrm{CCE}$ in a range of $\mathrm{N}$ concentrations and water alkalinities for impatiens, petunia, and pelargonium. Overall, the predicted $\mathrm{pH}$ effect of FS from the N CCE model were observed in the two experiments. However, the N CCE model is limited in scope (with just three species-specific $\mathrm{N}$ parameters) and predicted $\mathrm{pH}$ change would be improved with additional consideration of other ions such as $\mathrm{Ca}$ and $\mathrm{Mg}$ and substrate cation exchange capacity. Although the model predicted slightly higher $\mathrm{pH}$ as $\mathrm{NO}_{3}-\mathrm{N}$ concentration increased, the opposite $\mathrm{pH}$ trend was observed with a slight drop in $\mathrm{pH}$ from 100 to $200 \mathrm{mg} \cdot \mathrm{L}^{-1}$ $\mathrm{N}$ of the basic fertilizer in combination with the alkaline water source (Fig. 2), which may have resulted from increased $\mathrm{Ca}$ and $\mathrm{Mg}$ concentration and resulting acidification 
from cation exchange. The model was calibrated and validated with low- or no-leaching irrigation regimes. Given that increased leaching will reduce the substrate nutrient concentration and may also increase the impact of water quality on the salt composition in the root zone, further research should be conducted on the $\mathrm{pH}$ response of fertilizers with higher leaching rates. In the validation experiments reported here, and in the original Johnson et al. (2013) study, a non-residual lime source was used, which would not provide $\mathrm{pH}$ buffering, only one peat/perlite substrate was used, which would have lower cation exchange capacity than degraded peat or topsoil, and fertilizer was provided through fertigation. The scope of the model could also be expanded to account for other factors that commonly vary in floriculture production such as lime type, substrate components, and use of controlled-release solid fertilizers. Further study is needed to determine how a broader range in plant species and observed differences in iron efficiency of cultivars within a given plant species (Albano and Miller, 1998) impact substrate $\mathrm{pH}$ and in turn respond to substrate $\mathrm{pH}$ and thereby parameterize the N CCE model for other species and cultivars. It would also be useful for plant breeders and horticulture producers to know which Fe-efficiency processes dominate in container production of floriculture species such as cation-anion uptake balance, acid exudation by proton pumps, and iron reductase activity (Albano and Miller, 1996; Marschner, 1995; Taylor et al., 2008).

\section{Literature Cited}

Albano, J.P. and W.B. Miller. 1996. Iron deficiency stress influences physiology of iron acquisition in marigold (Tagetes erecta L.). J. Amer. Soc. Hort. Sci. 121:438-441.
Albano, J.P. and W.B. Miller. 1998. Marigold cultivars vary in susceptibility to iron toxicity. HortScience 33:1180-1182.

Argo, W.R. and J.A. Biernbaum. 1996. The effect of lime, irrigation-water source, and watersoluble fertilizer on root-zone $\mathrm{pH}, \mathrm{EC}$, and macronutrient management of container substrate with Impatiens. J. Amer. Soc. Hort. Sci. 121:442-452.

Argo, W.R. and J.A. Biernbaum. 1997. The effect of substrate on root-zone $\mathrm{pH}$, calcium, and magnesium management in containers with impatiens. J. Amer. Soc. Hort. Sci. 122:275284.

Argo, W.R. and P.R. Fisher. 2002. Understanding $\mathrm{pH}$ management for container-grown crops. Meister Publishing, Willoughby, OH.

Bailey, D.A., P.V. Nelson, and W.C. Fonteno. 1996. Bedding plant fertilization strategies N.C. Flower Growers Bul. 41:7-14.

Biernbaum, J.A. 1992. Root-zone management of greenhouse container-grown crops to control water and fertilizer use. HortTechnology 2:127132.

Biernbaum, J.A., M.V. Yelanich, W.R. Argo, D.D. Warncke, and D.M. Krauskopf. 1993. On-site soil testing training video and workbook. Professional Plant Growers Assoc., Lansing, MI.

Engels, C. and H. Marschner. 1995. Plant uptake and utilization of nitrogen, p. 41-82. In: Bacon, P.E. (ed.). Nitrogen fertilization in the environment. Marcel Dekker Inc., New York, NY.

Fisher, P.R., R.W. Dickson, G.S. MohammadPour, and J. Huang. 2014. Effect of solution electrical conductivity (EC) and pre-plant nutrient form on the $\mathrm{pH}$ of a peat-perlite substrate. Acta Hort. 1034:249-254.

Froehlich, D.M. and W.R. Fehr. 1981. Agronomic performance of soybeans with differing levels of iron deficiency chlorosis on calcareous soil. Crop Sci. 21:438-440.

Huang, J., P.R. Fisher, W.E. Horner, and W.R. Argo. 2010. Limestone particle size and residual lime concentration affect $\mathrm{pH}$ buffering in container substrates. J. Plant Nutr. 33:846858.
Johnson, C.N., P.R. Fisher, J. Huang, T.H. Yeager, T.A. Obreza, R.P. Vetanovetz, W.R. Argo, and A.J. Bishko. 2013. Effect of fertilizer potential acidity and nitrogen form on the $\mathrm{pH}$ response in a peat-based substrate with three floricultural species. Sci. Hort. 162:135143.

Lang, H.J. and G.C. Elliott. 1991. Influence of ammonium: Nitrate ratio and nitrogen concentration on nitrification activity in soilless potting media. J. Amer. Soc. Hort. Sci. 116:642-645.

Marschner, H. 1995. Mineral nutrition of higher plants. Academic Press, London, UK.

Peterson, J.C. 1981. Modify your $\mathrm{pH}$ perspective. Florist's Rev 169:34-35, 92-93.

Pierre, W.H. 1933. Determination of equivalent acidity and basicity of fertilizers. Ind. Eng. Chem. 5:229-234.

Puustjarvi, V. and R.A. Robertson. 1975. Physical and chemical properties, p. 23-38. In: Robinson, D.W. and J.G.D. Lamb (eds.). Peat in horticulture. Academic Press, London, UK.

Saxena, N. and A.R. Sheldrake. 1980. Iron chlorosis in chickpea (Cicer arietinum L.) grown on high $\mathrm{pH}$ calcareous vertisol. Field Crops Res. 3:211-214.

Taylor, M.D., P.V. Nelson, and J.M. Frantz. 2008. Substrate acidification by geranium: Temperature effects. J. Amer. Soc. Hort. Sci. 133:508514.

Verburg, K., J. Braschkat, Z. Hockman, A.D. Moore, K.R. Helyar, M.E. Probert, J.N.G. Hargreaves, and R.J. Simpson. 2003. Modeling acidification processes in agricultural systems, p. 135-187. In: Rengel, Z. (ed.). Handbook of soil acidity. Marcel Dekker Inc., New York, NY.

von Wiren, N., A. Gojon, S. Chaillou, and D. Raper. 2001. Mechanisms and regulation of ammonium uptake in higher plants, p. 61-77. In: Lea, P.J. and J.-F. Morot-Gaudry (eds.). Plant nitrogen. Springer, New York, NY.

Warncke, D.D. 1986. Analyzing greenhouse growth media by the saturation extraction method. HortScience 21:223-225. 